\title{
Dry matter yield, growth index, chemical composition and digestibility of Marandu grass under nitrogen and organic fertilization
}

\section{Produção de matéria seca, índices de crescimento, composição química e digestibilidade do capim Marandu sob fertilização nitrogenada e orgânica líquida}

\author{
Rafaela Guerra Neves ${ }^{1}$; Guilherme Santos Freitas ${ }^{1}$; Bruno Borges Deminicis ${ }^{2 *}$; \\ Eduardo de Sá Mendonça ${ }^{3}$; Anderson Lopes Peçanha ${ }^{3}$; Leonardo Barros Dobbss ${ }^{4}$; \\ Alberto Chambela Neto ${ }^{5}$; Renata Gomes da Silveira Deminicis ${ }^{6}$
}

\begin{abstract}
A pasture composed of the forage Brachiaria brizantha cv. Marandu, for more than 15 years and never fertilized, with an initial condition of degradation, was fertilized with nitrogen and humic substances, with the purpose Of recovering the vigor and productivity of the pasture. In the two years (December of 2012 to April 2013 and December 2014 to April 2015), analyses were made for dry matter production, plant height, light interception, leaf / stem ratio), chemical composition and digestibility of Brachiaria brizantha cv. Marandu. This was a completely randomized block experimental design, in a $5 \times 4$ arrangement, with five doses of nitrogen $(0,50,100,200,400 \mathrm{~kg}$ N.ha-1), four doses of humic substances $(0,12.5,25$ and 50\%), with 5 replicates. The forage presented lower means of dry matter production in the first year in relation to the second, but there was no difference for the chemical composition and digestibility between the years. There was a significant effect of Nitrogen levels on the production of dry matter, crude protein, silica, neutral detergent fiber (NDF), acid detergent fiber (FDA), and in vitro dry matter digestibility (DVMS). The best response was obtained with $200 \mathrm{~kg} \mathrm{~N} . \mathrm{ha}^{-1}$. The doses of humic substances influenced only reducing the leaf/stem ratio, but there was no effect of doses of humic substances on the other variables studied.
\end{abstract}

Key words: Liquid organic fertilization. Brachiaria brizantha. Urea.

\footnotetext{
1 Discentes de Mestrado, Programa de Pós-Graduação em Ciências Veterinárias, Universidade Federal do Espírito Santo, UFES, Alegre, ES, Brasil. E-mail: rafaelagneves@hotmail.com; guilhermesantosfreitas@hotmail.com

2 Prof., Centro de Formação em Ciências Agroflorestais, Universidade Federal do Sul da Bahia, UFSB, Ilhéus, BA, Brasil. E-mail: brunodeminicis@gmail.com

3 Profs., Centro de Ciências Agrárias e Engenharias, UFES, Alegre, ES, Brasil. E-mail: esmjplia@gmail.com; lopes.pecanha@ gmail.com

4 Prof., Instituto de Ciências Agrárias, Universidade Federal dos Vales do Jequitinhonha e Mucuri, UFVJM, Unaí, MG, Brasil. E-mail: dobbss@gmail.com

5 Prof., Instituto Federal do Espírito Santo, IFES, Campus Santa Teresa, ES, Brasil. E-mail: chambela@gmail.com

6 Discente de Doutorado, Programa de Pós-Graduação em Ciência Animal, Universidade Estadual de Santa Cruz, UESC, Ilhéus, BA, Brasil. E-mail: renatademinicis@gmail.com

* Author for correspondence
} 


\section{Resumo}

Uma pastagem formada com a forrageira Brachiaria brizantha cv. Marandu, a mais de 15 anos e nunca fertilizada, apresentando um quadro inicial de degradação, foi fertilizada com nitrogênio e substâncias húmicas, com o objetivo de recuperar o vigor e produtividade da pastagem. Nos dois anos (dez de 2012 a abril de 2013 e dezembro de 2014 a abril de 2015) foram avaliados: produção de matéria seca, altura das plantas, Interceptação luminosa, Relação folha/colmo), Composição química e Digestibilidade de Brachiaria brizantha cv. Marandu. O delineamento experimental foi o de blocos completamente casualizados, em um arranjo experimental $5 \times 4$, sendo cinco doses de nitrogênio $(0,50,100,200,400$ $\mathrm{kg} \mathrm{N} . \mathrm{ha}^{-1}$ ), quatro doses de substâncias húmicas (zero; 12,5; 25 e 50\%), com 5 repetições. No primeiro ano a forrageira apresentou médias de produção de matéria seca inferiores em relação ao segundo período, mas não houve diferença entre a composição química e digestibilidade do primeiro e o segundo ano. Verificou-se efeito significativo das doses de Nitrogênio na produção de matéria seca, proteína bruta, sílica, fibra em detergente neutro (FDN), fibra em detergente ácido (FDA), e digestibilidade da matéria seca in vitro (DVMS). A melhor resposta foi obtida com a dose de $200 \mathrm{~kg} \mathrm{~N}$.ha ${ }^{-1}$. As doses de substâncias húmicas influenciaram apenas reduzindo a relação folha/colmo, mas não foi evidenciado efeito de doses de substâncias húmicas sobre as demais variáveis estudadas.

Palavras-chave: Adubação orgânica líquida. Brachiaria brizantha. Uréia.

\section{Introduction}

The largest agricultural crop produced in Brazil is pasture, which occupies more than 180 million hectares, approximately $20 \%$ of the arable land of that territory, and 120 million hectares of cultivated pasture (IEIRI et al., 2010). In addition, the Brachiarias, introduced between 1960 and 1975, had a wide expansion in the Brazilian territory and tropical Americas, due to their exceptional adaptability to acid soils and low natural fertility. Among the species of Brachiaria, the most used is the Marandu grass (Brachiaria brizantha cv. Marandu), characterized by resistance to the spittlebug (Zulia spp. and Deois spp), good nutritive value, high dry matter and seed production capacity.

Forage consumption has a relevant role for a good performance of ruminants on pasture and one of the fundamental factors for the success of livestock exploitation is the pasture quality. At the same time, the production of animals causes solid, liquid and gaseous wastes during the production process, which can pollute and contaminate soil, water and air. The use as a productive input of these residues arouses great interest of the researchers, since it is directly related to the safety and protection of the environment.
According to Vitor et al. (2009), Brazilian livestock production is based on food support in pastures, but this is marked by a situation of extractive exploitation, where pastures in soils with low natural fertility, with no restitution of nutrients extracted by forages, inducing a condition of degradation and conditioning the loss of productive capacity of the pastures. Thus, Costa et al. (2010) evidenced that it is quite evident that reconstituting soil fertility, exhausted by years of extractive exploitation, is one of the ways to reverse the current situation of Brazilian pastures, being nitrogen considered the most demanding nutrient, thus the most important in an attempt to recover pastures that present loss of vigor.

The rational use of fertilizers is of great relevance for maximizing the economic efficiency of livestock activity and among the macronutrients, nitrogen plays a fundamental role in plant nutrition, being one of the main nutrients for maintaining productivity, influencing the quality of pasture (MISTURA et al., 2007). Nitrogen fertilization has been a key factor in the formation, maintenance and recovery of pastures, which has been one of the top 10 priorities in pastures exclusively of grasses (BONFIM-DA-SILVA; MONTEIRO, 2006). 
These substances have activity similar to that of plant hormones and increase nutrient uptake and plant growth (NARDI et al., 2002). The objective of this study was to evaluate the production, growth, chemical composition and digestibility of Brachiaria brizantha cv. Marandu subjected to doses of nitrogen and humic substances.

\section{Material and Methods}

The experiment was conducted in the private property Sítio Olho D’água, $-20^{\circ} 45^{\prime} 35.82$ “, $-41^{\circ}$ 25 '37.64", in the Municipality of Alegre, extreme south of the State of Espírito Santo, according to
Köppen classification, the climate of the region is Cwa, characterized by dry winter and rainy summer. The area consists of a strongly undulating and mountainous landscape. The study was carried out for two years (December from 2012 to April 2013 and December 2014 to April 2015). Historically, in this region the rainy period is hot and covers the months from October to April, while the dry period without rains, the minimum temperature is below $16^{\circ} \mathrm{C}$ and includes the months from May to October ( $25 \%$ rainfall yearly). The average annual rainfall is $1,200 \mathrm{~mm}$ and average annual temperature is $23^{\circ} \mathrm{C}$. However, during the experimental period, there was little rainfall (Figure 1).

Figure 1. Monthly Hydric Balance in the weather station of Alegre-ES from 2012 to 2015, Coordinates: LAT: 20,750 ${ }^{\circ}$ S LON: 41,488 ${ }^{\circ}$ W ALT: 129 m. Source: Capixaba Institute of Research, Technical Assistance and Rural Extension - INCAPER.
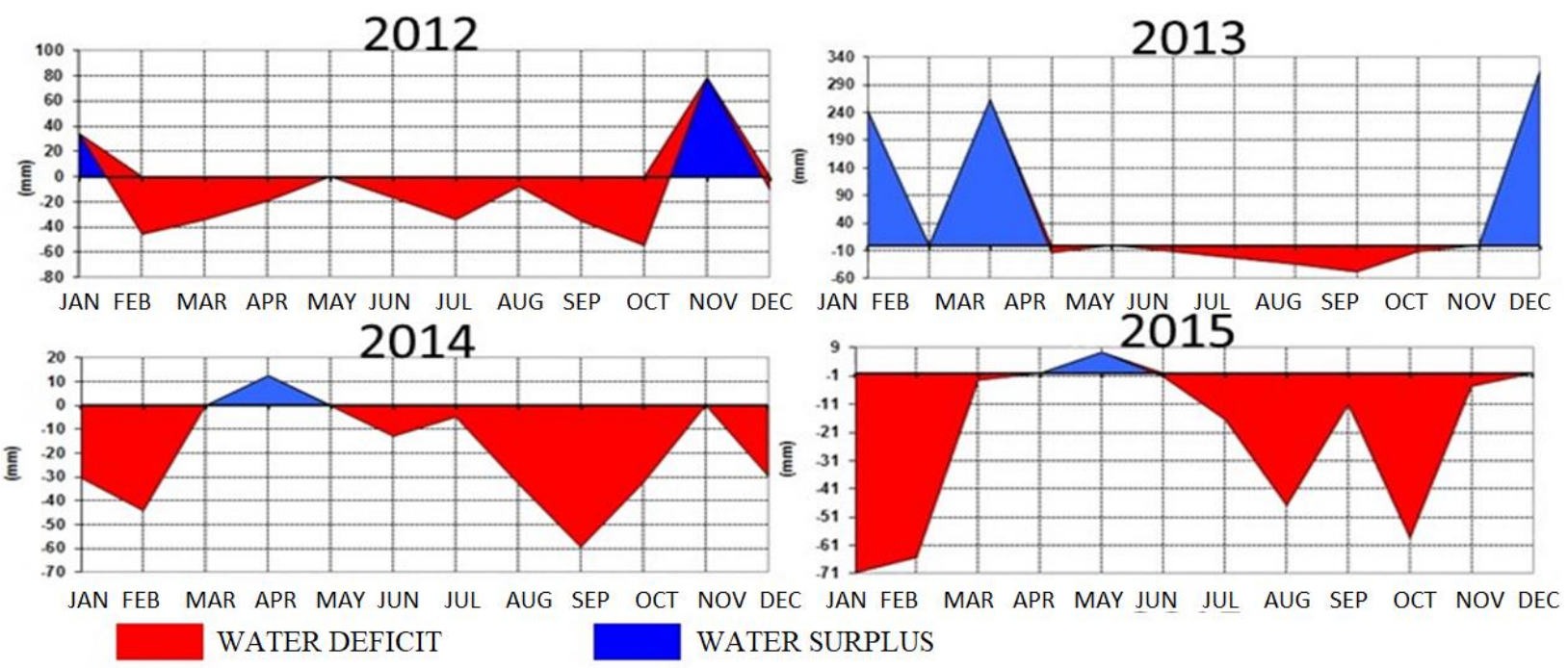

The experiment was a randomized block design in a $5 \times 4$ arrangement, with five doses of nitrogen $(0$, 50, 100, 200, $\left.400 \mathrm{~kg} \mathrm{~N} . \mathrm{ha}^{-1}\right)$, four doses of humic substances $(0,12.5,25$ and $50 \%$ of the extraction concentrate), in two repetitions in time (35 days after standardization cut and 35 days after) with five replicates.

The experimental area was $600 \mathrm{~m}^{2}$, being used the central $400 \mathrm{~m}^{2}$, formed by Brachiaria brizantha cv. Marandu for more than 15 years, never fertilized, presenting an initial condition of degradation, divided into 5 blocks with 20 plots of $4 \mathrm{~m}^{2}(2 \mathrm{~m} \times 2 \mathrm{~m})$ in each block. A soil analysis showed the following results: $\mathrm{pH}=5.8 ; \mathrm{P}=7.49 \mathrm{mg} / \mathrm{dm}^{3} ; \mathrm{K}=71.00 \mathrm{mg} /$ $\mathrm{dm}^{3} ; \mathrm{Na}=3.0 \mathrm{mg} / \mathrm{dm}^{3} ; \mathrm{Ca}=0.95 \mathrm{cmolC} / \mathrm{dm}^{3} ; \mathrm{Mg}$ $0.88=\mathrm{cmolC} / \mathrm{dm}^{3} ; \mathrm{Al}=0.00 \mathrm{cmolC} / \mathrm{dm}^{3} ; \mathrm{H}+\mathrm{Al}=$ $2.31 \mathrm{cmolC} / \mathrm{dm}^{3} ; \mathrm{SB}=2.02 \mathrm{cmolC} / \mathrm{dm}^{3} ; \mathrm{T}=2.02$ $\mathrm{cmolC} / \mathrm{dm}^{3} ; \mathrm{T}=4.33 \mathrm{cmolC} / \mathrm{dm}^{3} ; \mathrm{V}=46.59 \%, \mathrm{~m}$ $=0.00 \%$. From the results, liming, phosphate and potassium fertilization were carried out according 
to the recommendations of Prezotti et al. (2007), 0.52 T.ha $^{-1}$ calcitic limestone, $50 \mathrm{~kg} \cdot \mathrm{ha}^{-1}$ phosphorus as single superphosphate $\left(278 \mathrm{~kg}\right.$. ha $\left.{ }^{-1}\right), 60 \mathrm{~kg} \cdot \mathrm{ha}^{-1}$ potassium as potassium chloride $(104 \mathrm{~kg}$. ha-1).

At the implantation ( $1^{\text {st }}$ year $)$, as well as in the second year of the experiment, the plants were cut at $\mathrm{cm}$ from the ground, and the treatments were applied. Urea was used as a nitrogen source, applied diluted in water (10 liters per plot), the control plots received water in the same amount. Humic substances were extracted from vermicompost as determined by the International Humane Society (IHSS) and Zandonadi et al. (2013). After extraction, the composition was analyzed to determine the carbon concentration, finding the value of $20 \%$ of carbon. For the application of humic substances, a humic solution was produced by diluting the concentrated solution in water $(0 ; 12.5 ; 25$ and $50 \%$ ), and the solution was applied with costal sprayer in the proportion of 400 L.ha ${ }^{-1}$. After 40 days, the first evaluations were performed, with the central $1 \mathrm{~m}^{2}$ of each plot used for sampling. The following characteristics were evaluated: height of plants $(\mathrm{cm})$, interception of photosynthetically active radiation or, light interception (\%), dry matter (DM) production in T.ha ${ }^{-1}$, dry leaf yield (DL\%), crude protein content $(\mathrm{CP} \%)$, organic matter content $(\mathrm{OM} \%)$, soluble neutral detergent fiber (NDF), soluble acid detergent fiber (ADF), dry matter digestibility in vitro (DVMS \%), lignin (LIG\%) cellulose (CEL\%) and silica (SIL\%).

The height of the plants was determined, in the central square, with a graduated ruler. The light interception was measured using the Minipa digital luxmeter, model MLM-1011, after the evaluations. The central area was completely cut $10 \mathrm{~cm}$ from the ground and weighed in a digital dynamometer to determine the production and dry matter content. After weighing, a sub sample of approximately $500 \mathrm{~g}$ was taken for the other evaluations, according to Van Soest and Robertson (1985) and Silva and Queiroz (2002).
The leaf: stem ratio was calculated with a sample of approximately $200 \mathrm{~g}$. This, after weighed, was separated into leaf, stem, and weighed separately. A sample of approximately $200 \mathrm{~g}$ was oven-dried at $55^{\circ} \mathrm{C}$ for 96 hours, again weighed for dry matter determination. Subsequently, two more equally spaced evaluations were performed (40 days of defoliation interval). (40 days of defoliation interval).

For the determination of in vitro digestibility of dry matter (DVMS), we used the technique described by Tilley and Terry (1963), adapted to the artificial rumen, developed by $\mathrm{ANKON} \AA$, using instrument "Daisy incubator" from Ankom Technology (in vitro true digestibility IVTD). The ruminal fluid collection was performed by means of two male fistulated cattle with an average weight of $450 \mathrm{~kg}$, and the animals were kept on pasture of marandu.

The variables studied were analyzed using the statistical software SISVAR 5.3 (FERREIRA, 2010), developed by Universidade Federal de Lavras - UFLA. The results were tested by analysis of variance and regression at the 5\% level by F-test. The regression parameter estimates were evaluated by t-test at $5 \%$ significance.

\section{Results and Discussion}

The Meteorological Station of the Universidade Federal do Espírito Santo Provided the climatic variables. During the experimental period, in the $1^{\text {st }}$ year, the temperature ranged between 23.8 and $28.9^{\circ} \mathrm{C}$, relative humidity between 64.6 and $73.6 \%$, solar radiation between 16.3 and $26.5 \mathrm{MJ} / \mathrm{m}^{2}$, rainfall between 30.2 and $376.6 \mathrm{~mm}$ and average potential evapotranspiration between 5.07 and 5.18 mm.day ${ }^{-1}$. In the $2^{\text {nd }}$ year, the temperature varied between 24.3 and $29.5^{\circ} \mathrm{C}$, relative humidity from 52 to $73 \%$, solar radiation between 18 and $28 \mathrm{MJ} /$ $\mathrm{m}^{2}$, rainfall between 2.6 and $141 \mathrm{~mm}$ and average potential evapotranspiration of the period between 6.6 and 7.7 mm.day $^{-1}$. 
In the first year, the forage presented a mean dry matter yield (9.0 T DM.ha-1) higher than that of the second year (0.7 T DM.ha-1), however, for chemical composition and digestibility, there was no difference between the years. In relation to the effect of nitrogen and humic doses, in the second year, there was no effect on dry matter production, chemical composition and digestibility. These results are probably due to the low rainfall, high evapotranspiration and high level of solar radiation in 2015. The State of Espírito Santo, in
2015, experienced the worst drought of the last 40 years. A series of actions aimed at minimizing the effects of the lack of rain in which new irrigation facilities were banned, as well as the release of credit for such equipment. Based on this fact, it would not be possible to irrigate the pasture under study. However, a significant effect was observed of $\mathrm{N}$ rates on dry matter (DM) production in T.ha' ${ }^{-1}$, crude protein $(\mathrm{CP})$, silica, and in vitro dry matter digestibility (Tables 1 and 2).

Table 1. Mean values of productivity of dry matter (DM T.ha $\left.{ }^{-1}\right)$, organic matter content (OM\%), crude protein (CP\%), neutral detergent fiber content (NDF\%), acid detergent fiber content (ADF\%), Lignin (LIG\%), Cellulose content (CEL\%), silica content (SIL\%) and in vitro dry matter digestibility (DVMS) of Marandu grass according to nitrogen rates in the rainy-dry season transition season.

\begin{tabular}{cccccccccc}
\hline $\begin{array}{c}\mathrm{N} \\
\left(\text { Kg.ha }^{-1}\right)\end{array}$ & $\begin{array}{c}\text { DM } \\
\left(\mathrm{T} . h \mathrm{a}^{-1}\right)\end{array}$ & $\begin{array}{c}\text { MO } \\
(\%)\end{array}$ & $\begin{array}{c}\text { CP } \\
(\%)\end{array}$ & $\begin{array}{c}\text { NDF } \\
(\%)\end{array}$ & $\begin{array}{c}\text { ADF } \\
(\%)\end{array}$ & $\begin{array}{c}\text { LIG } \\
(\%)\end{array}$ & $\begin{array}{c}\text { CEL } \\
(\%)\end{array}$ & $\begin{array}{c}\text { SIL } \\
(\%)\end{array}$ & $\begin{array}{c}\text { DVMS } \\
(\%)\end{array}$ \\
\hline 0 & $2.60 \mathrm{c}$ & $88.91 \mathrm{a}$ & $7.01 \mathrm{~b}$ & $74.14 \mathrm{a}$ & $39.36 \mathrm{a}$ & $3.44 \mathrm{a}$ & $27.23 \mathrm{a}$ & $4.41 \mathrm{a}$ & $55.27 \mathrm{~b}$ \\
50 & $2.88 \mathrm{~b}$ & $89.15 \mathrm{a}$ & $7.01 \mathrm{~b}$ & $73.76 \mathrm{a}$ & $39.21 \mathrm{a}$ & $3.43 \mathrm{a}$ & $27.35 \mathrm{a}$ & $4.16 \mathrm{a}$ & $55.71 \mathrm{~b}$ \\
100 & $3.01 \mathrm{~b}$ & $89.06 \mathrm{a}$ & $7.24 \mathrm{~b}$ & $73.4 \mathrm{a}$ & $39.05 \mathrm{a}$ & $3.40 \mathrm{a}$ & $26.95 \mathrm{a}$ & $4.30 \mathrm{a}$ & $56.88 \mathrm{~b}$ \\
200 & $4.15 \mathrm{a}$ & $89.22 \mathrm{a}$ & $7.93 \mathrm{a}$ & $73.49 \mathrm{a}$ & $39.19 \mathrm{a}$ & $3.71 \mathrm{a}$ & $27.63 \mathrm{a}$ & $3.75 \mathrm{~b}$ & $57.88 \mathrm{a}$ \\
400 & $2.60 \mathrm{c}$ & $88.88 \mathrm{a}$ & $6.58 \mathrm{c}$ & $74.53 \mathrm{a}$ & $39.43 \mathrm{a}$ & $3.39 \mathrm{a}$ & $27.39 \mathrm{a}$ & $4.51 \mathrm{a}$ & $55.11 \mathrm{~b}$ \\
\hline $\mathrm{CV} \%$ & 21.06 & 1.72 & 8.39 & 2.01 & 4.76 & 9.74 & 2.42 & 15.13 & 8.6 \\
\hline
\end{tabular}

Mean values followed by different letters in the same column are significantly different by Tukey's test $(p>0.05)$.

These results were similar to those reported by Benett et al. (2008), who evaluated the effect of nitrogen doses $(0,50,100,150,200 \mathrm{~kg}$ of N.ha-1) on Brachiaria brizantha cv. Marandu, and verified an increase in dry matter production, improving the chemical composition by increasing the $\mathrm{CP}$ content and reducing the contents of NDF and ADF.

For the average dry matter production, considering the two years of study, as a function of the $\mathrm{N}$ doses, it was verified that with the increase of the $\mathrm{N}$ rates, an increase of the dry matter production was verified.. The production of DM increased up to the dose of $200 \mathrm{~kg} \mathrm{~N} . \mathrm{ha}^{-1}$, with subsequent reduction in DM production per $\mathrm{kg}$ of $\mathrm{N}$ applied at $400 \mathrm{~kg}$ of N.ha ${ }^{-1}$. It was verified that the dry matter production was $6.4 ; 7.5 ; 8.8 ; 14$ and $8.7 \mathrm{~kg} . \mathrm{ha}^{-1}$, in the first year and $0.77 ; 0.76 ; 0.68 ; 0.59$ and $0.60 \mathrm{~kg}^{-\mathrm{ha}^{-1}}$ in the second year, respectively at the doses of $0,50,100$, $150,200 \mathrm{~kg} \mathrm{~N} \cdot \mathrm{ha}^{-1}$. 
Table 2. Mean values of productivity of dry matter $\left(\mathrm{DM} \mathrm{T}^{\mathrm{T}} \mathrm{h}^{-1}\right)$, organic matter $(\mathrm{OM} \%)$, crude protein $(\mathrm{CP} \%)$, neutral detergent fiber (NDF\%), acid detergent fiber (ADF\%), Lignin (LIG\%), Cellulose (CEL\%), silica (SIL\%) and in vitro dry matter digestibility (IVDMD) of Marandu grass according to doses of Humic Substances in the dry-rainy transition season.

\begin{tabular}{cccccccccc}
\hline $\begin{array}{c}\text { SH } \\
(\%)\end{array}$ & $\begin{array}{c}\text { DM } \\
\left(\text { ton.ha }^{-1}\right)\end{array}$ & $\begin{array}{c}\text { MO } \\
(\%)\end{array}$ & $\begin{array}{c}\text { CP } \\
(\%)\end{array}$ & $\begin{array}{c}\text { NDF } \\
(\%)\end{array}$ & $\begin{array}{c}\text { ADF } \\
(\%)\end{array}$ & $\begin{array}{c}\text { LIG } \\
(\%)\end{array}$ & $\begin{array}{c}\text { CEL } \\
(\%)\end{array}$ & $\begin{array}{c}\text { SIL } \\
(\%)\end{array}$ & $\begin{array}{c}\text { DVMS } \\
(\%)\end{array}$ \\
\hline 0 & $3.00 \mathrm{a}$ & $88.64 \mathrm{a}$ & $8.86 \mathrm{a}$ & $72.15 \mathrm{a}$ & $39.21 \mathrm{a}$ & $3.72 \mathrm{a}$ & $27.29 \mathrm{a}$ & $4.00 \mathrm{a}$ & $56.23 \mathrm{a}$ \\
12,5 & $2.78 \mathrm{a}$ & $88.63 \mathrm{a}$ & $8.90 \mathrm{a}$ & $72.20 \mathrm{a}$ & $38.95 \mathrm{a}$ & $3.73 \mathrm{a}$ & $27.32 \mathrm{a}$ & $4.08 \mathrm{a}$ & $\begin{array}{c}56.29 \mathrm{a} \\
25\end{array}$ \\
$2.69 \mathrm{a}$ & $88.69 \mathrm{a}$ & $8.82 \mathrm{a}$ & $71.88 \mathrm{a}$ & $38.77 \mathrm{a}$ & $3.60 \mathrm{a}$ & $26.82 \mathrm{a}$ & $4.17 \mathrm{a}$ & $56.34 \mathrm{a}$ \\
50 & $2.63 \mathrm{a}$ & $88.89 \mathrm{a}$ & $8.73 \mathrm{a}$ & $72.62 \mathrm{a}$ & $39.02 \mathrm{a}$ & $3.62 \mathrm{a}$ & $27.12 \mathrm{a}$ & $4.09 \mathrm{a}$ & $56.81 \mathrm{a}$ \\
\hline $\mathrm{CV} \%$ & 24.64 & 1.91 & 9.40 & 1.99 & 3.59 & 9.42 & 3.43 & 14.11 & 6.16 \\
\hline
\end{tabular}

Mean values followed by different letters in the same column are significantly different by Tukey's test ( $p>0.05)$.

In addition, an effect was found for $\mathrm{N}$ doses on plant height $(\mathrm{cm})$, light interception (\%) and leaf dry matter yield, without significant effect on the leaf: stem (F: C) ratio.

There was a general increase in dry matter (DM) production from the lowest to the highest dose. The maximum dose, $400 \mathrm{~kg}$ of N.ha-1 ${ }^{-1}$ presented a production of $3 \mathrm{~T}^{-h^{-1}}$, similar results to those found by Magalhães et al. (2007), Fagundes et al. (2006). According to Magalhães et al. (2007), nitrogen fertilization promotes an increase in leaf: stem ratio, improves the nutritive value and increases forage yield.

Alexandrino et al. (2004) working with Brachiaria brizantha vc. Marandu under three doses of nitrogen, (0, 20 and $40 \mathrm{mg} \cdot \mathrm{dm}^{-3}$ N.week $\left.{ }^{-1}\right)$, concluded that the influence of $\mathrm{N}$ doses on dry matter production is due to both emergence and increase in the weight of the tillers, in which the plants that did not receive the supply of $\mathrm{N}$ present lower tillering. The authors also add that from the $32^{\text {nd }}$ day of regrowth, for $\mathrm{N}$ levels, the average weight of tiller tended to stabilization. According to Abreu et al. (2004), this indicates the high responsiveness of this forage to the applications of this nutrient.

Silva et al. (2009) evaluated Brachiaria decumbens in a greenhouse and also observed that the use of nitrogen fertilization influenced the number of tillers per plant and that plants that did not receive nitrogen had practically no increase of tillers.

The height of the plants presented a significant difference between the doses of $\mathrm{N}$, but did not present the height not differed when using different humic acid doses (Figure 1). The effect of $\mathrm{N}$ doses on plant height was linear, where the highest height was found at the dose of 400 T.ha $^{-1}$. Results that corroborate Castagnara et al. (2011) who evaluated the effect of nitrogen fertilization on the height of the forage canopy, and concluded that the height of the forage canopy increases linearly with the increase of $\mathrm{N}$ doses applied.

The doses of humic substances influenced only the leaf: stem ratio among the analyzed variables. The results allow us to expect that this material present the best result regarding the development of the root system due to the intimate contact of these substances with the roots of the plants (SILVA et al., 2009), which was not evaluated in this study. The response of the aerial part depends on other variables, such as the raw material used to extract the humic substances, their origin, the functional groups present in the humic substances and their reactivity (AYUSO et al., 1996).

Rodrigues et al. (2008) found that $\mathrm{N}$ rates $(0$, 75,150 and $225 \mathrm{mg} . \mathrm{dm}^{-3}$ ) were responsible for the increase in dry mass production and the production of total dry mass and that higher production were 
observed at higher doses of this nutrient. Primavesi et al. (2006) analyzed the efficiency of nitrogen utilization by Brachiaria brizantha cv. Marandu and reported that the best indices occurred with the lowest doses of $\mathrm{N}$.

According to Andrade et al. (2000), the nitrogen plays a key role in plant nutrition, is an essential constituent and interferes directly with the process of light interception in the photosynthetic process, because of its participation in the chlorophyll molecule. Considering the indices of limping interception, we observed an upward behavior regarding the increase of $\mathrm{N}$ doses, not influenced by the doses of humic substances, reaching the intercept of $97.5 \%$ with the maximum dose of 400 T.ha $^{-1} \mathrm{~N}$ (Figure 2).

Cecato et al. (2004) evaluated the crude protein in forage dry matter under nitrogen fertilization $(0$; 200; 400; $600 \mathrm{~kg}$ of N.ha-1) and phosphorus $(0 ; 50$; $\left.100 ; 150 ; 200 \mathrm{~kg} \mathrm{P}_{2} \mathrm{O}_{5} \cdot \mathrm{ha}^{-1}\right)$, found that $\mathrm{CP}$ levels of Marandu grass showed a linear behavior ( $\mathrm{P}$ $<0.05)$ with increasing nitrogen levels. This shows increases in CP in DM, with the use of nitrogen.

Moreira et al. (2009) evaluated the chemical composition of Brachiaria grass subjected to nitrogen fertilization $(75,150,225$ and $300 \mathrm{~kg}$ N. ha ${ }^{-1}$.year ${ }^{-1}$ for two years, applied every month, and obtained results that show that nitrogen doses promote a linear increase in $\mathrm{CP}$ concentrations in leaves.

Oliveira et al. (2010) verified the influence of combinations of nitrogen doses on pastures of brachiaria in recovery, which showed an increase in $\mathrm{CP}$ concentrations, ranging from 14.4 to $18.8 \%$ in the first evaluation. In addition, the authors observed $6.2-14.7 \%$ in the second evaluation and $7.4-11.9 \%$ in the fifth evaluation, emphasizing the responsiveness of Brachiaria brizantha cultivars to nitrogen fertilization, raising CP levels to values considered adequate for feeding cattle, where the levels of CP were above the critical level of $7 \%$, limiting consumption by cattle.
The content of NDF in the plant showed a significant reduction with $200 \mathrm{~kg} \mathrm{~N} . \mathrm{ha}^{-1}$ reaching 69.19\%. Deminicis et al. (2010), when evaluating the response to the application of nitrogen doses associated with potassium in the NDF content, verified that there was no effect of growth intervals and $\mathrm{N}$ and $\mathrm{K}_{2} \mathrm{O}$ doses).

Costa et al. (2010) reported influence of $\mathrm{N}$ doses, promoting a reduction in the NDF content, finding averages between $70 \%$ and $64 \%$ for the control. The maximum dose studied, respectively, showing reduction of $8.9 \%$ in relation to the control.

Ruviaro et al. (2012) reported that doses higher than $110 \mathrm{Kg} \cdot \mathrm{ha}^{-1}$ resulted in a higher NDF content, which differs from the results found in this experiment and in other reports in the literature.

Costa et al. (2010) studied the effect of nitrogen doses and sources on the recovery of marandu grass, for a period of three years in a pasture established for over 10 years, and obtained results that show a reduction in $\mathrm{ADF}$ values with the increase in $\mathrm{N}$ doses. According to these authors, this reduction is considered important, because this parameter influences the digestibility of the food, thus compromising the performance of the animals. In studies of the influence of nitrogen doses $(100,200$, $300,400 \mathrm{~kg} \cdot \mathrm{ha}^{-1} \cdot$ year $^{-1}$ ) on the chemical composition of elephantgrass, Mistura et al. (2007) found that nitrogen fertilization increased NDF levels. Other authors, however, did not detect marked differences in NDF contents in response to nitrogen fertilization (COSTA et al., 2010).

Nitrogen fertilization promotes an increase in leaf elongation rate, resulting in a direct effect on the photosynthetic leaf area (MARTUSCELLO et al., 2005). In addition to this influence, $\mathrm{N}$ is a controlling factor of the different processes of plant growth and development and provides increase of biomass due to the increase in carbon fixation. Thus, larger area for energy capture promotes greater accumulation of biomass (MARTUSCELLO et al., 2005). $\mathrm{N}$ doses influenced the dry matter yield of leaves in a linear 
way, in which, at the dose of $400 \mathrm{~kg} \mathrm{~N} \cdot \mathrm{ha}^{-1}$ the yield of 2.88 T.ha $^{-1}$ was obtained (Figure 3).

Results similar to those found by Martuscello et al. (2005), who worked with Xaraés grass, testing four nitrogen doses, and observed an increase of up to $37 \%$ in leaf elongation rate $\left(\mathrm{cm} \cdot \mathrm{day}^{-1}\right)$ for the highest $\mathrm{N}$ dose in relation to the absence of nitrogen fertilization. According to Silva et al. (2012), nitrogen fertilization increases the leaf appearance rate as well as the leaf elongation rate.

Leaf dry matter production is important for forage growth, since the leaf blade is the most photosynthetically active component in the leaf, so it has a close correlation with high leaf : thatch values. Fagundes et al. (2006) applied doses of $\mathrm{N}$ in brachiaria at different times of the year and concluded that the increase in the doses caused a linear effect mainly on the final length of the leaf, as well as on the leaf elongation rate and the leaf area index.

The leaf/stem ratio was significant as regards humic substances (Figure 4), showing a negative linear behavior, where the increase in the humic substances concentration increased the leaf differentiation, reducing the leaf/stem ratio. Similar results were found by Peçanha (2012), who tested different doses of humic acid in brachiaria, and concluded that successive applications of this humic material favored the increase of stem diameter.

The dry mass production was essentially composed of leaves, on average $95 \%$, due to the short interval of defoliation, which justifies the absence of significance for leaf/stem ratio between the different doses of nitrogen. Results similar were obtained by Rodrigues et al. (2008), which performed defoliation with 41 days of rest and observed absence of significance for leaf/stem ratio for different $\mathrm{N}$ rates due to the reduced age of the plants. The elongation of stems increases the forage production, but interferes with the sward structure, which impairs the grazing efficiency due to the reduced volume of leaves in relation to the volume of stems, which is directly related to the performance of the grazing animals (EUCLIDES et al., 2000).

The DVMS was influenced by the doses of nitrogen, having at $200 \mathrm{~kg} \mathrm{~N} \cdot \mathrm{ha}^{-1}$ its highest percentages. Ruviaro et al. (2012), when evaluating elephantgrass response to IVDMD, in terms of digestibility values, found linear responses in relation to the applied $\mathrm{N}$ rates, and at the highest $200 \mathrm{~kg} \mathrm{~N} \cdot \mathrm{ha}^{-1}$, they obtained the highest digestibility of the forage, sow of $69 \%$.

Climatic conditions, such as luminosity, temperature and rainfall, which promote greater growth, can influence the chemical composition of plants, as they may cause accumulation of dead material and greater metabolic activity, converting the photosynthesis products into structural tissues, increasing the cell wall, increasing the NDF and the $\mathrm{ADF}$, thus reducing protein content and DVMS.

Among the several factors related to the management of forage plants, such as age of cut, fertilization, plant morphological characteristics, cutting height or grazing height at which the plant submitted can influence the nutritional value of forage plants, since lower cuts, usually promote greater removal of the stem fraction, which can reduce $\mathrm{CP}$ content, digestibility and intake (EUCLIDES et al., 2000).

Nitrogen doses did not affect the silica content of the forage, which is a good thing, since silica is present in the plant cell wall and, like lignin, limits the digestibility of the forage by providing physical resistance to the plant, for being a structural element, providing greater rigidity to the cell wall (VAN SOEST, 1994). Brâncio et al. (2002) estimated the chemical characteristics of the dry matter of three cultivars of Panicum maximum Jacq. Subjected to different doses of nitrogen and found that after the grazing period, the silica content remained constant in all treatments; according to the same authors, 
the high silica content is related to less palatability and lower intake, since it is not absorbed by the animals and acts as a physical barrier to microbial colonization on the leaf blade.

The doses of humic substances did not influence the variables analyzed. Fagundes et al. (2006) found that root development of ryegrass (Lolium multiflorum) was stimulated by humic substances, so the results showed that humic substances favored root growth, increasing by $100.87 \%$, When the dose of humic substances increased from 0 to $20 \mathrm{mg} . \mathrm{L}^{-1}$, these substances had positive effects on plant metabolism, stimulating root elongation (the coefficients of determination of the obtained equations indicate that more than $90 \%$ of root lengthening was due to the effect of humic substances). In the case of pastures in process of degradation, there is a decrease in shoot production in the degraded pasture accompanied by a decrease in the number of roots in the soil profile and a concentration of the root system near the surface.

Thus, possibly when receiving the doses of nitrogen associated with the doses of humic substances, the pasture increased the dry matter production of the aerial and radicular parts, recovering their organic reserves.

In order to determine the presence of water in the soil, the photosynthesis and the translocation of these organic reserves in the plant depend on the opening and closing of the stomata and the activity of the metabolic sinkins. However, for tropical and subtropical grasses, regrowth may not depend exclusively on the content of reserve compounds, at the time of cutting or grazing, but also on the remaining leaf area. In fact, it occurred in the two study years, since the cutting height of the plants was $10 \mathrm{~cm}$ from the ground, leaving few residual leaves, although it is routinely recommended the height of grazing at $10 \mathrm{~cm}$. In this way, we can admit a high reduction in carbohydrate content after defoliation, because it was a pasture at the beginning of degradation, and probably mobilized to meet the new growth. However, the effect cannot be verified in the second year of the study because of the regional water deficit.

\section{Acknowledgments}

To Embrapa, Fapes and to CAPES for financial support.

\section{References}

ABREU, J., CÓSER, A. C., DEMINICIS, B. B., BRUM, R. P., SANT'ANA, N. D. F., TEIXEIRA, M. C., \& SANTOS, A. 2004. Avaliação da produção de matéria seca, relação folha/colmo e composição químicobromatológica de Brachiaria humidicola (rendle), submetida à diferentes idades de rebrota e doses de nitrogênio e potássio. Revista Universidade Rural, v. 24, p.135-141. Disponível em: http://www.ufrrj.br/SEER/ index.php?journal $=$ rcv\&page $=$ issue $\& o p=$ viewIssue $\& p$ ath $\% 5 \mathrm{~B} \% 5 \mathrm{D}=210 \&$ path $\% 5 \mathrm{~B} \% 5 \mathrm{D}=133$. Acesso em: 28 maio 2019.

ALEXANDRINO, E.; NASCIMENTO JÚNIOR, D.; MOSQUIM, P. R.; REGAZZI, A. J.; ROCHA, F. C. Características morfogênicas e estruturais na rebrotação da Brachiaria brizantha cv. Marandu submetida a três doses de nitrogênio. Revista Brasileira de Zootecnia, Viçosa, MG, v. 33, n. 6, p. 1372-1379, 2004. DOI: 10.1590/S1516-35982004000600003

ANDRADE, A. C.; FONSECA, D. M.; GOMIDE, J. A.; ALVAREZ, V. V. H.; MARTINS, C. E; SOUZA, D. P. H. Produtividade e valor nutritivo do capimelefante cv. Napier sob doses crescentes de nitrogênio e potássio. Revista Brasileira de Zootecnia, Viçosa, MG, v. 29 , n. 6 , p. $1589-1595,2000$. DOI: $10.1590 /$ S151635982000000600001

AYUSO, M.; HERNANDEZ, T.; GARCIA, C.; PASCUAL, J. A. Stimulation of barley growth and nutrient absorption by humic substances originating from various organic materials. Bioresource and Technology, Kidlington, v. 57, n. 3, p. 251-257, 1996. DOI: 10.1016/ S0960-8524(96)00064-8

BENETT, C. G. S.; BUZZETTI, S.; SILVA, K. S.; BERGAMASCHINE, A. F.; FABRICIO, J. A. Produtividade e composição bromatológica do capim marandu a fontes e doses de nitrogênio. Ciência e Agrotecnologia, Lavras, v. 32, n. 5, p. 1629-1636, 2008. Disponível em: http://www.scielo.br/pdf/cagro/ v32n5/41.pdf. Acesso em: 28 maio 2019. 
BONFIM-DA-SILVA, E. M.; MONTEIRO, F. A. Nitrogênio e enxofre em características produtivas do capim-braquiária proveniente de área de pastagem em degradação. Revista Brasileira de Zootecnia, Viçosa, MG, v. 35, n. 4, p. 1289-1297, 2006. DOI: 10.1590/ S1516-35982006000500006

BRÂNCIO, P. A.; NASCIMENTO JÚNIOR, D.; EUCLIDES, V. P. B. Avaliação de três cultivares de Panicum maximum Jacq. sob pastejo, composição química e digestibilidade da forragem. Revista Brasileira de Zootecnia, Viçosa, MG, v. 31, n. 4, p. 1605-1613, 2002. DOI: $10.1590 /$ S1516-35982002000700002

CASTAGNARA, D. D.; MESQUITA E. E.; NERES, M. A.; OLIVEIRA, P. S. R.; DEMINICIS, B. B.; BAMBERG, R. Valor nutricional e características estruturais de gramíneas tropicais sob adubação nitrogenada. Archivos de Zootecnia, Córdoba, v. 60, n. 232, p. 931-942, 2011. Disponível em: https://www.uco.es/ucopress/az/index. php/az/article/view/3978/2334. Acesso em: 28 maio 2019.

CECATO, U.; PEREIRA, L. A. F.; JOBIM, C. C.; MARTINS, E. N.; BRANCO, A. F.; GALBEIRO, S.; MACHADO, A. O. Influência das adubações nitrogenadas e fosfatadas sobre a composição químico-bromatológica do capim-marandu (Brachiaria brizantha) (Hochst) Stapf cv. Marandu). Acta Scientiarum, Animal Sciences, Maringá, v. 26, n. 3, p. 409-416, 2004. Disponível em: http://ojs.uem.br/ojs/index.php/ActaSciAnimSci/article/ download/1837/1187. Acesso em: 28 maio 2019.

COSTA, K. A. P.; FAQUIN, V.; OLIVEIRA, I. P. Doses e fontes de nitrogênio na recuperação de pastagens do capim-marandu. Arquivo Brasileiro de Medicina Veterinária e Zootecnia, Belo Horizonte, v. 62, n. 1, p. $115-$ 123, 2010. DOI: 10.1590/S0102-09352010000100026

DEMINICIS, B. B.; ABREU, J. B. R.; VIEIRA, H. D.; ARAÚJO, S. A. C. Brachiaria humidicola (Rendle) Schweick em diferentes idades de rebrota submetida a doses de nitrogênio e potássio. Ciência e Agrotecnologia, Lavras, v. 34, n. 5, p. 1116-1123, 2010. DOI: 10.1590/ S1413-70542010000500006

EUCLIDES, V. P. B.; CARDOSO, E. G.; MACEDO, M. C. M.; OLIVEIRA, M. P. Consumo voluntário de Brachiaria decumbens cv. Basilisk e Brachiaria brizantha cv. Marandu sob pastejo. Revista Brasileira de Zootecnia, Viçosa, MG, v. 29, n. 6, p. 2200-2208, 2000. Suplemento 2. Disponível em: http://www.sbz.org.br/ revista/artigos/2660.pdf. Acesso em: 28 maio 2019.

FAGUNDES, J. L.; FONSECA, D. M.; MISTURA, C.; MORAIS, R. V.; VITOR, C. M. T.; GOMIDE, C. A.; NASCIMENTO JÚNIOR, D.; CASAGRANDE, D. R.; COSTA, L. T. Características morfogênicas e estruturais do capim-braquiária em pastagem adubada com nitrogênio avaliadas nas quatro estações do ano. Revista Brasileira de Zootecnia, Viçosa, MG, v. 35, n. 1, p. 21 29, 2006. DOI: 10.1590/S1516-35982006000100003

FERREIRA, D. F. SISVAR: sistema de análise de variância. Versão 5.3. Lavras: UFLA, 2010. (Software estatístico). Disponível em: http://www.dex.ufla. br/ danielff/programas/sisvar.html. Acesso em: 28 maio 2019.

IEIRI, Y. I.; LANA, R. M. Q.; KORNDORFER, G. H.; PEREIRA, H. S. Fontes, doses e modos de aplicação de fósforo na recuperação de pastagem com brachiaria. Ciência e Agrotecnologia, Lavras, v. 34, n. 5, p. 11541160, 2010. DOI: 10.1590/S1413-70542010000500011

MAGALHÃES, A. F.; PIRES, A. J. V.; CARVALHO, G. G. P. de; SILVA, F. F. da; SOUSA, R. S.; VELOSO, C. M. Influência do nitrogênio e do fósforo na produção do capim-braquiária. Revista Brasileira de Zootecnia, Viçosa, MG, v. 36, n. 5, p. 1240-1246, 2007. DOI: $10.1590 / \mathrm{S} 1516-35982007000600004$

MARTUSCELLO, J. A.; FONSECA, D. M.; NASCIMENTO JÜNIOR, D.; SANTOS, P. M.; RIBEIRO JUNIOR, J. I.; CUNHA, D. N. F. V.; MOREIRA, L. M. Características morfogênicas e estruturais do capim-massai submetido a adubação nitrogenada e desfolhação. Revista Brasileira de Zootecnia, Viçosa, MG, v. 35, n. 3, p. 665-671, 2005. DOI: 10.1590/S151635982006000300006

MISTURA, C.; FONSECA, D. M.; MOREIRA, L. M. Efeito da adubação nitrogenada e irrigação sobre a composição químico bromatológica das lâminas foliares e da planta inteira de capim-elefante sob pastejo. Revista Brasileira de Zootecnia, Viçosa, MG, v. 36, n. 6, p. $1707-$ 1714, 2007. DOI: 10.1590/S1516-35982007000800002

MOREIRA, L. M.; MARTUSCELLO, J. A.; FONSECA, D. M.; MISTURA, C.; MORAES, R. V.; RIBEIRO JUNIOR, J. I. Perfilhamento, acúmulo de forragem e composição bromatológica do capim-braquiária adubado com nitrogênio. Revista Brasileira de Zootecnia, Viçosa, MG, v. 38, n. 9, p. 1675-1684, 2009. DOI: 10.1590/ S1516-35982009000900006

NARDI, S.; PIZZEGHELlO, D.; MUSCOLO, A.; VIANELLO,A. Physiological effects of humic substances on higher plants. Soil Biology and Biochemistry, v. 34 , n. 11 , p. 1527-1536, 2002. DOI: $10.1016 / \mathrm{S} 0038-$ 0717(02)00174-8

OLIVEIRA, L. B.; PIRES, A. J. V.; CARVALHO, G. G. P. Produtividade, composição química e características agronômicas de diferentes forrageiras. Revista Brasileira de Zootecnia, Viçosa, MG, v. 39, n. 12, p. 2604-2610, 2010. DOI: $10.1590 / \mathrm{S} 1516-35982010001200007$ 
PEÇANHA, A. L. Efeito de diferentes doses e épocas de aplicação de ácidos húmico no crescimento inicial de Brachiaria decumbens. In: IX REUNIÃO BRASILEIRA DE BIOLOGIA DO SOLO, 2012, Maceió. Anais... Maceió: Sociedade Brasileira de Ciência do Solo, 2012. CD-ROM.

PREZOTTI, L. C.; GOMES, J. A.; DADALTO, G. G.; OLIVEIRA, J. A. Manual de recomendação de calagem e adubação para o Estado do Espírito Santo. $5^{a}$ aproximação. Vitória: SEEA/Incaper/Cedagro, 2007. $301 \mathrm{p}$.

PRIMAVESI, A. C.; PRIMAVESI, O.; CORRÊA, L. A.; SILVA, A. G.; CANTARELLA, H. Nutrientes na fitomassa de capim marandu em função de fontes e doses de nitrogênio. Ciência e Agrotecnologia, Lavras, v. 30 , n. 3 , p. $562-568,2006$. DOI: $10.1590 / \mathrm{S} 1413-$ 70542006000300024

RODRIGUES, R. C.; MOURÃO, G. B.; BRENNECKE, K.; LUZ, P. H. C.; HERLING, V. R. Produção de massa seca, relação folha/colmo e alguns índices de crescimento do Brachiaria brizantha cv. Xaraés cultivado com a combinação de doses de nitrogênio e potássio. Revista Brasileira de Zootecnia, Viçosa, MG, v. 37, n. 3, p. 394400, 2008. DOI: 10.1590/S1516-35982008000300003

RUVIARO, C.; SILVA, A. M.; BEM, C. A. V.; DORNELES, J. G. Modificação morfológica e qualitativa de capim elefante, submetida à lâmina de irrigação e a diferentes doses de adubação em cobertura, na região do vale do Jaguari - RS. Perspectiva, Erechim, v. 36, n. 135, p. 15-26, 2012. Disponível em: http://www.uricer.edu.br/ site/pdfs/perspectiva/135 286.pdf. Acesso em: 28 maio 2019.

SILVA, C. C. F.; BONOMO, P.; PIRES, A. J. V.; MARANHÃO, C. M. A.; PATÊS, N. M. S.; SANTOS, L. C. Características morfogênicas e estruturais de duas espécies de braquiária adubadas com diferentes doses de nitrogênio. Revista Brasileira de Zootecnia, Viçosa, MG, v. 38, n. 4, p. 657-661, 2009. DOI: DOI: 10.1590/S151635982009000400010
SILVA, D. J.; QUEIROZ, A. C. Análise de alimentos: métodos químicos e biológicos. 2. ed. Viçosa, MG: Universidade Federal de Viçosa, 2002. 235 p.

SILVA, T. C. da; PERAZZO, A. F.; MACEDO, C. H. O.; BATISTA, E. D.; PINHO, R. M. A.; BEZERRA, H. F. C.; SANTOS, E. M. Morfogênese e estrutura de Brachiaria decumbens em resposta ao corte e adubação nitrogenada. Archivos de Zootecnia, Córdoba, v. 61, n. 233, p. 91102, 2012. Disponível em: https://www.uco.es/ucopress/ az/index.php/az/article/view/2945. Acesso em: 28 maio 2019.

TILLEY, J. M. A.; TERRY, R. A. A two stage technique for in vitro digestion of forages crops. Journal of the British Grassland Society, Cambridge, v. 18, n. 2, p. 104111, 1963. DOI: 10.1111/j.1365-2494.1963.tb00335.x

VAN SOEST, P. J.; ROBERTSON, J. B. Analysis of forage and fibrous foods. Ithaca: Dept. Animal Sci. Cornell University, 1985. 202 p.

VAN SOEST, P. J. Nutritional ecology of the ruminant. Cowallis: O. \& Books, 1994. 476 p.

VITOR, C. M. T.; FONSECA, D. M.; CÓSER, A. C.; MARTINS, C. E.; NASCIMENTO JÚNIOR, D.; RIBEIRO JÚNIOR, J. I. Produção de matéria seca e valor nutritivo de pastagem de capim-elefante sob irrigação e adubação nitrogenada. Revista Brasileira de Zootecnia, Viçosa, MG, v. 38, n. 3, p. 435-442, 2009. DOI: 10.1590/ S1516-35982009000300006

ZANDONADI, D. B.; SANTOS, M. P.; BUSATO, J. G.; PERES, L. E. P.; FAÇANHA, A. R. Plant physiology as affected by humified organic matter. Theoretical and Experimental Plant Physiology, Campo dos Goytacazes, v. 25 , n. 1 , p. $12-25,2013$. DOI: 10.1590/S219700252013000100003 
